\title{
Penentuan Pusat-pusat Kegiatan Baru sebagai Alternatif untuk Mengurangi Kemacetan Kota Bogor
}

\author{
Determination of New Regional Growth Center \\ as an Alternative to Reduce Congestion of Bogor City \\ Dewi Annisa Rizki ${ }^{*}$, Ernan Rustiadi ${ }^{2}$ \& Soekmana Soma ${ }^{2}$

\begin{abstract}
${ }^{1}$ Program Studi Ilmu Perencanaan Wilayah, Sekolah Pascasarjana, Institut Pertanian Bogor, Kampus IPB Dramaga , Bogor 16680; ${ }^{2}$ Departemen Ilmu Tanah dan Sumberdaya Lahan, Fakultas Pertanian, Institut Pertanian Bogor, Kampus IPB Dramaga, Bogor 16680; "Penulis korespondensi. e-mail: dewiannisarizki@gmail.com
\end{abstract}

(Diterima: 22 Februari 2017; Disetujui: 18 September 2017)

\begin{abstract}
Bogor city is facing very serious congestion problems. Rearrangement of the spatial structure of the urban growth centers could improve the city's transportation system. This study aims to map the density of traffic, analyze the hierarchy of growth centers, analyze the spatial interactions and formulate alternative arrangement of the centers of the new activities. The study was conducted through descriptive analysis, Schallogram method, the Spatial Gravitation Model and TOPSIS. Schallogram analysis is used to analyze the hierarchy level of service. The Gravity Model is used to analyze the interaction between the regions. TOPSIS analysis is used to identify priority areas and new growth centers. This study analyzed data on the volume of vehicles, facilities area, population, road length, road network maps, and spatial plan (RTRW). The areas in the city center had the highest traffic density and the highest hierarchical. While suburban areas tend to have the lowest hierarchy. Based on the results of gravity model analysis, the areas with the highest attraction located in the city center and extends along the corridor to the north and the south. While the production area spread around the suburbs. Based on the analysis TOPSIS recommend new growth centers, namely Margajaya, Cimahpar, and Bojongkerta.
\end{abstract}

Keywords: congestion, regional hierarchy, center

\section{ABSTRAK}

Kota Bogor merupakan kota penyangga Ibu Kota DKI Jakarta. Permasalahan kemacetan merupakan salah satu permasalahan yang ada di kota Bogor. Untuk mengatasi kemacetan, perbaikan sistem perkotaan perlu dilakukan dengan menetapkan pusat kegiatan baru. Penelitian ini bertujuan untuk memetakan 1) kepadatan lalu lintas, 2) hierarki wilayah, 3) interaksi wilayah, dan 4) alternatif pusat kegiatan baru. Metode analisis data yang digunakan adalah analisis Deskriptif, Skalogram, Gravitasi dan TOPSIS. Analisis Skalogram untuk mengetahui tingkat hierarki wilayah. Analisis Gravitasi digunakan untuk mengetahui interaksi antar wilayah. Analisis TOPSIS untuk merumuskan prioritas wilayah pusat pertumbuhan baru. Data yang digunakan dalam penelitian ini adalah volume kendaraan, jumlah fasilitas wilayah, jumlah populasi penduduk, panjang jalan, peta jaringan jalan, dan peta RTRW. Wilayah yang memiliki kepadatan lalu lintas tinggi adalah wilayah-wilayah yang berada di pusat kota. Berdasarkan analisis Skalogram, wilayah hierarki satu cenderung ada di pusat kota, sedangkan hierarki lima cenderung ada di pinggiran kota. Berdasarkan hasil analisis gravitasi bahwa secara spasial wilayah tarikan berada ditengah dan memanjang kearah Utara dan Selatan 
sedangkan wilayah bangkitan menyebar di pinggiran kota. Berdasarkan hasil analisis TOPSIS, arahan wilayah pengembangan pusat kegiatan adalah di pinggiran kota yang berbatasan dengan kabupaten Bogor yaitu kelurahan Margajaya, kelurahan Cimahpar, dan kelurahan Bojongkerta.

Kata kunci: kemacetan, hierarki wilayah, pusat

\section{PENDAHULUAN}

Transportasi merupakan bagian yang tidak terpisahkan dari tata ruang sebagai penghubung antar wilayah dan kegiatan. Transportasi menempati ruang yang tersebar membentuk jaringan di dalam dan antar ruang kegiatan. Disini letak perbedaan transportasi dengan guna lahan lainnya yang pada umumnya membentuk kawasan dengan batas-batas yang jelas. Kedudukan transportasi adalah menjembatani semua kegiatan manusia di dalam struktur wilayah.

Fungsi dari transportasi adalah untuk memobilisasi arus pergerakan orang dan barang. Pergerakan atau perjalanan terjadi karena manusia melakukan aktivitas di tempat yang berbeda dengan daerah tempat mereka tinggal. Kegiatan mobilitas produsen dan konsumen dari dan menuju lokasi interaksi untuk menggerakan roda perekonomian membutuhkan sarana dan prasarana transportasi. Pergerakan perekonomian dalam suatu wilayah berimplikasi terhadap perkembangan wilayah itu sendiri, sehingga pergerakan dalam sistem transportasi memiliki peran penting dalam perkembangan wilayah. Demikian pula, dengan semakin berkembangnya suatu wilayah dibutuhkan ketersediaan sarana dan prasarana transportasi yang memadai.

Menurut Tamim (2000), besarnya pergerakan sangat berkaitan erat dengan jenis dan intensitas kegiatan yang dilakukan. Kota Bogor memiliki tingkat intensitas kegiatan tinggi, hal ini menjadikan tingkat kepadatan lalu lintas pun tinggi. Besarnya pergerakan lalu lintas di Kota Bogor menimbulkan berbagai permasalahan, salah satunya permasalahan transportasi. Permasalahan transportasi di antaranya kemacetan semakin kompleks dijumpai di Kota Bogor. Kemacetan merupakan salah satu permasalahan transportasi yang terjadi hampir di setiap ruas Kota Bogor.

Kemacetan umumnya terjadi pada jamjam sibuk di pagi dan sore hari. Untuk mengatasi permasalahan transportasi utamanya kemacetan, tidak dapat diselesaikan hanya oleh satu bidang ilmu. Menurut Black (1981) dalam Tamim (2000), setidaknya ada 4 profesi yang berpengaruh dalam sistem transportasi yaitu ahli jalan raya, ahli lalu lintas, pengelola angkutan umum dan perencana wilayah. Kontribusi perencana wilayah dalam pergerakan lalu lintas adalah dengan mengatur lokasi aktivitas suatu penggunaan lahan (landuse) atau tata guna lahan agar dapat pula mengatur aksesibilitas kota tersebut.

Permasalahan transportasi merupakan permasalahan multifaktor dan multidisiplin. Permasalahan transportasi tidak mungkin dapat terselesaikan dalam satu bidang ilmu apalagi satu penelitian saja. Batasan dalam penelitian ini adalah dalam lingkup perencana wilayah, utamanya penatagunaan lahan.

Menurut Gulo (2015), pusat pertumbuhan merupakan salah satu alternatif untuk menggerakan dan memacu pembangunan. Pertumbuhan wilayah juga dapat meningkatkan aksesibilitas masyarakat dengan di bangunnya jaringan jalan baru, sebagaimana diungkapkan Rui et.al (2013), bahwa pertumbuhan jaringan jalan semakin meningkat manakala pusat-pusat kegiatan semakin banyak.

Pertumbuhan pusat kegiatan itu sendiri terlihat dari perubahan pola penggunaan lahannya. Menurut Kumalasari (2015), penggunaan lahan mempengaruhi pergerakan lalu lintas. Transportasi dan tata guna lahan berhubungan sangat erat, Bau (2013) menyebutnya sebagai satu land-use transport system. Sistem transportasi yang tidak baik akan menghalangi aktivitas tata guna lahan. Sebaliknya, transportasi yang tidak melayani 
suatu tata guna lahan akan menjadi sia-sia, tidak termanfaatkan.

Tujuan penelitian ini adalah untuk mengurangi kemacetan di pusat Kota Bogor, adapun sasarannya adalah untuk mengetahui (1) Kepadatan lalu lintas di Kota Bogor; (2) Hierarki wilayah di Kota Bogor; (3) Interaksi wilayah di Kota Bogor; serta (4) Alternatif wilayah pengembangan pusat pertumbuhan.

\section{METODE PENELITIAN}

\section{Analisis Kepadatan Lalu Lintas}

Kepadatan lalu lintas suatu ruas jalan dapat tergambar dari Tingkat Pelayanan Jalan yang diperoleh berdasarkan derajat kejenuhan ruas jalan tersebut. Derajat Kejenuhan merupakan rasio dari arus lalu lintas ruas jalan (Q) terhadap Kapasitas ruas jalan (C).

Berdasarkan MKJI (1997), arus lalu-lintas ruas jalan (Q) adalah jumlah atau banyaknya kendaraan yang melewati suatu titik tertentu pada ruas jalan dalam suatu satuan waktu tertentu. Nilai arus lalu-lintas $(\mathrm{Q})$ mencerminkan komposisi lalu-lintas, dengan menyatakan arus dalam satuan mobil penumpang (smp). Nilai arus lalu lintas ini juga dikenal dengan sebutan volume kendaraan pada ruas jalan. Semua nilai arus lalu-lintas diubah menjadi satuan mobil penumpang (smp). Dengan menggunakan ekivalensi mobil penumpang (emp) yang diturunkan secara empiris untuk tiga tipe kendaraan yaitu kendaraan ringan (LV), kendaraan herat (HV) dan sepeda motor (MC). Jumlah kendaraan dari masing-masing tipe dikalikan dengan nilai ekivalensi mobil penumpang (emp) untuk distandarisasi ke dalam satuan mobil penumpang (smp).

Perhitungan arus lalu lintas ruas jalan adalah dengan persamaan (MKJI,1997):

$\mathrm{Q}=\mathrm{QLV}+\mathrm{QHV} \times \mathrm{empHV}+\mathrm{QMC} \times \mathrm{empMC}$

Dimana :

$\mathrm{Q}=$ arus lalu lintas ruas jalan ( $\mathrm{smp} / \mathrm{jam})$

QLV = jumlah kendaraan sedang hasil Pengamatan
QHV = jumlah kendaraan berat hasil pengamatan

empHV= faktor pengali untuk kendaraan berat

QMC =jumlah sepeda motor hasil pengamatan

empMC = faktor pengali untuk sepeda motor

Kapasitas jalan perkotaan dihitung dari kapasitas dasar. Kapasitas dasar adalah jumlah kendaraan maksimum yang dapat melintasi suatu penampang pada suatu jalur atau jalan selama 1 (satu) jam. Besarnya kapasitas jalan dapat dijabarkan pada persamaan (MKJI, 1997):

$$
\mathrm{C}=\mathrm{C}_{0} \times \mathrm{FCw} \times \mathrm{FCsp} \times \mathrm{FCsf} \times \mathrm{FCcs}
$$

\section{Dimana :}

$\mathrm{C}=$ kapasitas ruas jalan ( $\mathrm{smp} / \mathrm{jam})$

$\mathrm{C}_{0} \quad=$ kapasitas dasar

$\mathrm{FCw}=$ faktor penyesuaian kapasitas untuk lebar jalur lalu-lintas

FCsp = faktor penyesuaian kapasitas untuk pemisahan arah

FCsf $=$ faktor penyesuaian kapasitas untuk hambatan samping

FCcs $=$ faktor penyesuaian kapasitas untuk ukuran kota.

Setelah memperoreh nilai arus lalu lintas (Q) dan nilai Kapasitas (C) untuk ruas-ruas jalan yang diamati, maka dapat melihat perilaku lalu lintas dalam hal ini kepadatan ruas jalan. Kepadatan lalu lintas tersebut digambarkan oleh Derajat Kejenuhan (Ds) yang memiliki persamaaan (MKJI, 1997):

$$
D s=\frac{Q}{C}
$$

Dimana :

$$
\begin{array}{ll}
\mathrm{Q} & =\text { Arus Lalu Lintas }(\mathrm{SMP} / \mathrm{Jam}) \\
\mathrm{C} & =\text { Kapasitas ruas jalan }(\mathrm{SMP} / \mathrm{Jam})
\end{array}
$$

Nilai derajat kejenuhan ini, umum juga disebut dengan V/C R (volume per capacity ratio) Setelah nilai Ds atau V/C R didapatkan, kemudian dilakukan klasifikasi berdasarkan tingkat pelayanan jalan. Karakteristik tingkat 
pelayanan jalan atau Level of Service (LOS) tersaji pada tabe 11 .

Tabel 1. Karakteristik tingkat pelayanan jalan

\begin{tabular}{|c|c|c|}
\hline $\begin{array}{l}\text { Tingkat } \\
\text { Pelayanan }\end{array}$ & Karakteristik & $\begin{array}{l}\text { Batas } \\
\text { V/C } \\
\text { Ratio }\end{array}$ \\
\hline A & $\begin{array}{l}\text { Arus bebas dengan volume lalu } \\
\text { lintas rendah dan kecepatan } \\
\text { tinggi; }\end{array}$ & $\begin{array}{l}0.00- \\
0.20\end{array}$ \\
\hline B & $\begin{array}{l}\text { Arus stabil dengan volume lalu } \\
\text { lintas sedang dan kecepatan } \\
\text { mulai dibatasi oleh kondisi lalu } \\
\text { lintas }\end{array}$ & $\begin{array}{l}0.20- \\
0.44\end{array}$ \\
\hline $\mathrm{C}$ & $\begin{array}{l}\text { Arus stabil tetapi kecepatan dan } \\
\text { pergerakan kendaraan } \\
\text { dikendalikan oleh volume lalu } \\
\text { lintas yang lebih tinggi; }\end{array}$ & $\begin{array}{l}0.45- \\
0.74\end{array}$ \\
\hline $\mathrm{D}$ & $\begin{array}{l}\text { Arus mendekati tidak stabil } \\
\text { dengan volume lalu lintas } \\
\text { tinggi dan kecepatan masih } \\
\text { ditolerir namun } \\
\text { terpengaruh oleh perubahan } \\
\text { kondisi arus; }\end{array}$ & $\begin{array}{l}0.75- \\
0.84\end{array}$ \\
\hline $\mathrm{E}$ & $\begin{array}{l}\text { Arus tidak stabil, dengan } \\
\text { volume lalu lintas mendekati } \\
\text { kapasitas jalan dan kecepatan } \\
\text { sangat rendah; }\end{array}$ & $\begin{array}{l}0.85- \\
1.00\end{array}$ \\
\hline $\mathrm{F}$ & $\begin{array}{lrr}\text { Arus tertahan dan } & \text { terjadi } \\
\text { antrian } & \text { kendaraan } & \text { yang } \\
\text { panjang; } & & \\
\end{array}$ & $\geq$ \\
\hline
\end{tabular}

Untuk mendapatkan peta kepadatan lalu lintas wilayah, maka V/C R setiap ruas dalam suatu wilayah diambil nilai rata-rata, kemudian dibagi menjadi 5 kelas. Interval antar kelas diambil dengan perhitungan:

$$
\text { Interval }=\frac{\text { Ds Tertinggi }- \text { Ds Terendah }}{5}
$$

Klasifikasi kepadatan lalu lintas wilayah tersebut yaitu wilayah dengan kepadatan lalu lintas Rendah, Cukup Rendah, Sedang, Cukup Tinggi, dan Tinggi. Semakin tinggi nilai Ds menunjukan kepadatan lalu lintas wilayahnya pun semakin tinggi.

\section{Analisis Hierarki}

Sudarya et.al (2013) mengungkapkan, penetuan hierarki wilayah atau identifikasi wilayah pusat dan wilayah pendukung
(Hinterland) penting dilakukan untuk menentukan prioritas wilayah pembangunan.

Hierarki wilayah ditunjukkan oleh kelengkapan fasilitas yang tersedia pada masingmasing wilayah. Wilayah dengan fasilitas yang lebih lengkap menujukan bahwa wilayah tersebut memiliki hierarki lebih tinggi (Hierarki1). Untuk melihat hierarki wilayah yang berpotensi dikembangkan, dilakukan analisis skalogram. Pada penelitian ini, selain ditentukan oleh jumlah fasilitas yang tersedia juga dimodifikasi dengan jarak terdekat terhadap fasilitas di wilayah tetangga apabila di wilayah tersebut tidak terdapat fasilitas, hal ini sebagaimana yang dilakukan Panuju dan Rustiadi (2012).

Dalam metode Skalogram, wilayah yang berpotensi sebagai pusat kegiatan adalah berhierarki lebih tinggi (Hierarki-1) dan sebaliknya semakin sedikit sarana dan prasarana yang tersedia maka akan memilki hierarki semakin rendah.

Data yang digunakan dalam analisis skalogram adalah: (a) data jarak terdekat dengan sarana kegiatan; (b) data jumlah dan jenis sarana pendidikan; (c) data jumlah dan jenis sarana perkantoran; (d) data jumlah dan jenis pusat perbelanjaan.

Tahapan dalam melakukan analisis skalogram dengan bantuan perangkat lunak Excel adalah sebagai berikut :

1. Tahapan awal dalam melakukan analisis skalogram adalah mengelompokan 2 variabel yaitu variabel positif berupa jumlah fasilitas dan variabel negatif berupa jarak terdekat dari fasilitas. Variabel positif adalah variabel yang semakin besar nilainya mencirikan wilayah dengan tingkat perkembangan lebih tinggi. Sebaliknya variabel negatif adalah variabel yang semakin besar nilainya mencirikan hierarki atau tingkat perkembangan yang lebih rendah.

2. Menjumlahkan masing-masing fasilitas, serta menjumlahkan wilayah yang dianalisis. Pada penelitian ini jumlah wilayah yang dianalisis adalah 68 yaitu jumlah kelurahan yang ada di Kota Bogor. 
3. Menghitung indeks fasilitas per 1000 penduduk pada kelompok A dengan cara menghitung nilai indeks fasilitas dengan persamaan (Panuju dan Rustiadi, 2012):

Dimana :

$$
A_{i j}=1000 \times \frac{F_{i j}}{P_{i}}
$$

$\mathrm{A}_{\mathrm{ij}}=$ indeks fasilitas ke-j di wilayah ke-i

$F_{i j}=$ jumlah fasilitas ke-j di wilayah ke-i

$\mathrm{P}_{\mathrm{i}}=$ jumlah penduduk di wilayah ke-i

Hasil perhitungan indeks fasilitas per kapita tersebut kemudian dijumlahkan pada baris dan kolom.

4. Menghitung invers indeks data pada kelompok B dengan menggunakan persamaan (Panuju dan Rustiadi, 2012):

Dimana :

$$
B_{i j}=\frac{1}{X_{i j}}
$$

$B_{i j}=$ indeks invers data

$\mathrm{X}_{\mathrm{ij}}=$ nilai data wilayah ke-i variabel ke-j

Pada tahap penghitungan ini ditemukan variabel-variabel dengan nilai 1/Xij sama dengan "\#DIV/0!", hasil tersebut diperoleh ketika $X_{i j}$ bernilai 0 . Untuk itu nilai “\#DIV/0!” perlu diganti dengan nilai maksimum dari indeks invers data.

5. Tahap selanjutnya adalah dengan menghitung bobot indeks penciri menggunakan persamaan (Panuju dan Rustiadi, 2012):

Dimana :

$$
I_{i j}=\frac{X_{i j} n}{X_{i j} a_{j}}
$$

$\mathrm{I}_{\mathrm{ij}}=$ bobot indeks penciri

$\mathrm{X}_{\mathrm{ij}}=$ nilai data wilayah ke-i variabel ke- $\mathrm{j}$

i $=1,2, \ldots, n$ menunjukan jumlah wilayah

$\mathrm{j}=1,2, \ldots, \mathrm{p}$ menunjukan jumlah seluruh variabel penciri

Selanjutnya, menghitung nilai minimum dan standar deviasi untuk kebutuhan tahap berikutnya.
6. Tahap berikutnya adalah melakukan pembakuan indeks untuk seluruh variabel termasuk variabel kelompok A dan kelompok B, sehingga hasil akhir adalah indeks baku yang diperoleh dari persamaan (Panuju dan Rustiadi, 2012):

$$
\mathrm{K}_{\mathrm{ij}}=\frac{\left(\mathrm{I}_{\mathrm{ij}}-\min \left(\mathrm{I}_{\mathrm{j}}\right)\right)}{\mathrm{S}_{\mathrm{j}}}
$$

Sedangkan untuk menentukan indeks perkembangan (wilayah) kelurahan jumlah nilai baku indeks hierarki pada (wilayah) kelurahan tersebut:

$$
I P K=\sum \frac{\left(I_{i j}-\min \left(I_{j}\right)\right)}{S_{j}}
$$

Dimana :

$$
\begin{array}{ll}
\mathrm{K}_{\mathrm{ij}} & =\text { nilai baku indeks hierarki } \\
& \text { untuk wilayah ke-i dan ciri } \\
& \text { ke- } \mathrm{j} \\
= & \text { bobot indeks penciri untuk } \\
& \text { wilayah ke-i dan ke- } \mathrm{j}
\end{array}
$$

7. Tahapan paling akhir adalah melakukan klasifikasi hierarki wilayah ke dalam 5 kelas dengan interval masing-masing kelas menggunakan persamaan:

$$
\text { Interval }=\frac{3}{5} \times S_{j}
$$

Klasifikasi dalam analisis skalogram ini terdiri dari 5 hierarki, dimana hierarki tertinggi adalah hierarki 1. Wilayah yang memiliki hierarki 1 merupakan wilayah yang berpotensi untuk menjadi pusat kegiatan baru.

\section{Analisis Interaksi Wilayah}

Secara garis besar, analisis interaksi wilayah merupakan analisis yang menitikberatkan pada tiga unsur yaitu jarak, massa dan pergerakan. Dalam analisis model gravitasi unsur-unsur tersebut di wakili oleh populasi pada wilayah asal (mi) dan tujuan (mj), aliran orang moda jalan (Tij) dan jarak (dij) 
berupa panjang jalan. Sebagaimana diungkapkan Jati dan Christanto (2012), menentukan jarak antar wilayah adalah dengan menggunakan data panjang jalan, hal ini dinilai lebih mengakomodasi analisis gravitasi. Data panjang jalan antar kelurahan yang digunakan dalam penelitian ini bersumber dari Dinas Bina Marga dan Sumber Daya Air Kota Bogor Tahun 2015. Wilayah dalam penelitian ini adalah 68 kelurahan yang berada Kota Bogor.

Model gravitasi dapat dirumuskan dengan persamaan (Panuju dan Rustiadi, 2012):

$$
\mathrm{T}_{\mathrm{ij}}=\mathrm{k} \frac{\mathrm{m}_{\mathrm{i}}^{\alpha} \mathrm{m}_{\mathrm{j}}^{\beta}}{\mathrm{d}_{\mathrm{ij}}^{\mathrm{c}}}
$$

Penyelesaian persamaan ini dipecahkan dengan pendekatan fungsi regresi linier dengan terlebih dahulu mentranformasikan ke dalam bentuk logistik normal (ln), sehingga menjadi:

$$
\ln T_{i j}=\ln k+\alpha \ln m_{i}+\beta \ln m_{j}-c \ln d_{i j}
$$

Dimana :

$$
\begin{array}{ll}
\mathrm{T}_{\mathrm{ij}} & =\text { Interaksi antar wilayah } \mathrm{i} \text { dan } \mathrm{j} \\
\mathrm{m}_{\mathrm{i}} & =\text { populasi wilayah } \mathrm{i} \\
\mathrm{m}_{\mathrm{j}} & =\text { populasi wilayah } \mathrm{j} \\
\mathrm{d}_{\mathrm{ij}} & =\text { jarak antar wiayah } \mathrm{i} \text { dan } \mathrm{j} \\
\alpha, \beta, \mathrm{c} & =\text { koefisien variabel populasi i, populasi } \\
& \mathrm{j} \text { dan jarak dari } \mathrm{i} \text { ke } \mathrm{j} \\
\mathrm{k} & =\text { konstanta }
\end{array}
$$

Model gravitasi kemudian dapat dikembangkan untuk melihat model potensial dengan model persaingan lokasi pasar, sebagaimana dirumuskan:

$$
V_{i}=\frac{1}{D} \sum_{j=1}^{n} \frac{m_{j}^{\beta}}{d_{i j}^{c}}, i \neq j
$$

$$
\begin{aligned}
& \text { Dimana } \quad \sum_{i} \sum_{j} \frac{m_{j}^{\beta}}{d_{i j}^{c}}=\mathrm{D} \\
& \mathrm{V}_{\mathrm{j}}=\frac{1}{\mathrm{D}} \sum_{\mathrm{i}=1}^{\mathrm{n}} \frac{\mathrm{m}_{\mathrm{i}}^{\alpha}}{\mathrm{d}_{\mathrm{ij}}^{\mathrm{c}}}, \mathrm{i} \neq \mathrm{j}
\end{aligned}
$$

$$
\text { Dimana } \quad \sum_{i} \sum_{j} \frac{m_{i}^{\alpha}}{d_{i j}^{c}}=\mathrm{D}
$$

Dimana :

$\mathrm{V}_{\mathrm{i}} \quad=$ Model potensial

$\mathrm{V}_{\mathrm{j}} \quad=$ Model persaingan pasar

$\mathrm{m}_{\mathrm{i}} \quad=$ populasi wilayah $\mathrm{i}$

$\mathrm{m}_{\mathrm{j}} \quad=$ populasi wilayah $\mathrm{j}$

$\alpha, \beta, c=$ koefisien variabel populasi i, populasi $\mathrm{j}$ dan jarak dari i ke j

Dasar untuk menentukan karakteristik suatu wilayah sebagai wilayah pembangkit atau sebagai wilayah penarik, adalah dengan melihat rasio antara nilai potensial (Vi) dengan nilai persaingan lokasi pasar $(\mathrm{Vj})$. Apabila nilai Vi lebih besar dari $\mathrm{Vj}$ maka wilayah tersebut merupakan wilayah pembangkit/produksi. Sebaliknya, apabila nilai Vi lebih kecil dari nilai $\mathrm{Vj}$ maka wilayah tersebut merupakan wilayah penarik/pasar.

\section{AHP TOPSIS}

Arahan pusat kegiatan wilayah Kota Bogor dirumuskan melalui kombinasi dari metode AHP (Analytical Hierarchy Process) dan TOPSIS (Technique for Others Reference by Similarity to Ideal Solution). Metode AHP digunakan untuk menentukan pembobotan terhadap kriteria yang telah ditentukan sehingga mengurangi subjektivitas penilaian pada kriteria-kriteria yang dijadikan sebagai input dan kemudian dilakukan perangkingan. Technique For Order Preference By Similarity To Ideal Solution (TOPSIS) merupakan salah satu metode pengambilan keputusan melalui pengukuran kinerja relatif dari alternatif-alternatif keputusan dalam bentuk matematis sederhana (Fitriana et al., 2015).

Secara umum tahapan dalam analisis TOPSIS adalah: (1) Menentukan matriks keputusan yang ternomalisasi, (2) Menghitung matriks keputusan ternormalisasi yang terbobot, (3) Menghitung matriks solusi ideal positif dan matriks solusi ideal negatif, (4) Menghitung jarak antara nilai setiap alternatif dengan matriks solusi ideal positif dan matriks solusi ideal negatif, (5) Menghitung nilai preferensi untuk setiap alternatif.

Dalam perangkingan kelurahan menggunakan TOPSIS maka ada kriteria yang 
harus dimaksimumkan atau diminimumkan dengan berbagai pertimbangan sebagaimana tersebut di atas. Perangkingan didasarkan pada pertimbangan kepadatan lalu lintas wilayah, hierarki wilayah dan interaksi wilayah. Dalam penelitian ini, kriteria kepadatan lalu lintas dipilih yang minimum, kriteria hierarki wilayah dipilih yang memiliki hierarki tertinggi, dan kriteria interaksi wilayah dipilih yang wilayah pasar. Dari hasil perangkingan tersebut diketahui wilayah yang dapat dijadikan alternatif sebagai pusat kegiatan.

Pada penelitian ini untuk melakukan analisis TOPSIS dilakukan dengan menggunakan software Sanna. Wilayah terpilih sebagai alternatif pusat kegiatan adalah wilayah yang memiliki nilai R.U.V (Range Unit Value) tertinggi. Nilai R.U.V sebagai cerminan dari kedekatan relatif dari alternatif kecamatan ke-i terhadap solusi ideal positif sehingga altenatif kelurahan dengan nilai R.U.V tertinggi/ terbesar merupakan solusi yang terbaik.

\section{HASIL DAN PEMBAHASAN}

\section{Kepadatan Lalu Lintas Kota Bogor}

Pergerakan lalu lintas kendaraan tertinggi di Kota Bogor adalah pada ruas jalan akses tol. Selanjutnya diikuti pergerakan ke dan dari pusat kota serta kawasan peralihan (Hinterland). Hal ini dikarenakan pola pengembangan tata ruang Kota Bogor yang terkonsentrasi di bagian tengah, sedangkan di daerah pinggiran dominan dengan kawasan hunian/pemukiman. Ruas-ruas jalan dengan tingkat pelayanan terendah adalah jalan Sukasari 3, Jalan Tanjung Biru, Jalan Sancang, Jalan Raya Sukabumi, Jalan Nyi Raja Permas, Jalan Kapten Muslihat, Jalan Pengadilan, Jalan Dewi Sartika, Jalan Siliwangi, Jalan Lawang Seketeng, Jalan R. Shaleh Syarif Bustaman (Raya empang) dan Jalan Pahlawan.
Dapat digambarkan bahwa ruas-ruas jalan tersebut memiliki arus yang tidak stabil dengan volume lalu lintas tinggi, fluktuasi volume lalu lintas dan hambatan temporer dapat menyebabkan penurunan kecepatan yang besar. Hal ini menyebabkan pengemudi memiliki kebebasan yang sangat terbatas dalam menjalankan kendaraan. Jika kondisi ini dialami dalam waktu singkat masih dapat ditolerir, akan tetapi ketika dialami pada waktu yang panjang maka kondisinya akan sangat tidak nyaman. Peta Tingkat Pelayanan Jalan Kota Bogor tersaji dalam Gambar 1.

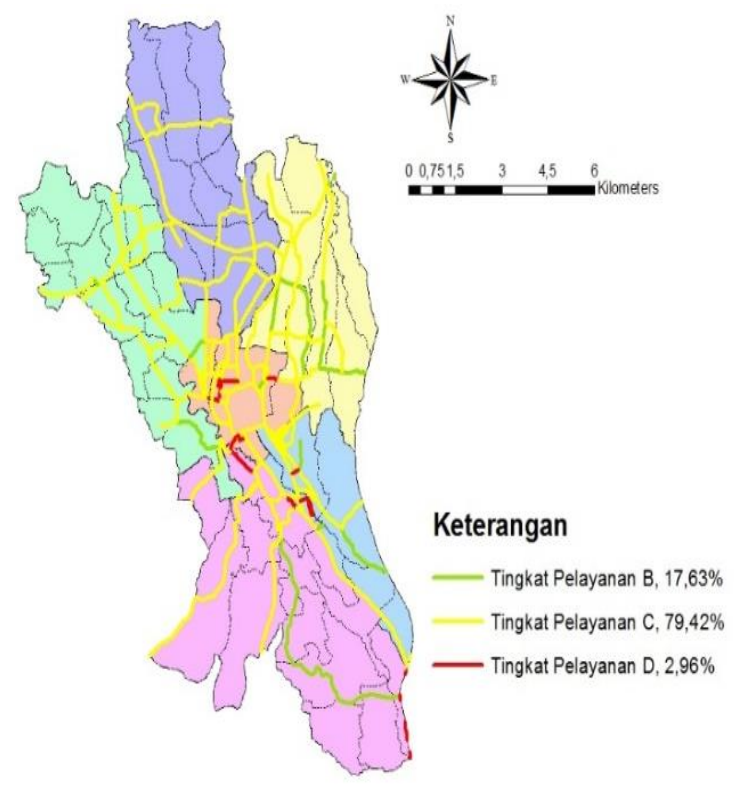

Gambar 1. Peta tingkat pelayanan jalan Kota Bogor

Berdasarkan peta tingkat pelayanan jalan, dapat terlihat ruas-ruas jalan yang memiliki derajat kejenuhan yang hampir jenuh berada di pusat kota. Untuk membuat peta kepadatan lalu lintas wilayah, maka diambil nilai rata-rata dari v/c ratio ruas-ruas jalan pada tiap wilayah kelurahan. Secara spasial kewilayahan kepadatan lalu lintas di Kota Bogor tersaji dalam Gambar 2. 


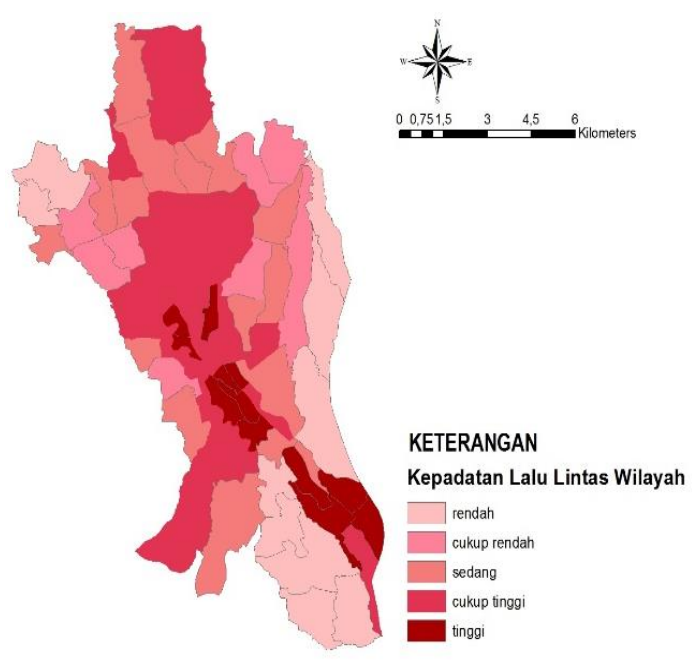

Gambar 2. Peta kepadatan lalu lintas wilayah Kota Bogor

Berdasarkan peta tingkat pelayanan jalan, dapat terlihat ruas-ruas jalan yang memiliki derajat kejenuhan yang hampir jenuh berada di pusat kota. Hal ini sejalan dengan besarnya penggunaan lahan di pusat kota yangdidominasi oleh lahan terbangun terutama guna lahan jasa dan perdagangan.

\section{Hierarki Wilayah Kota Bogor}

Hierarki Kota Bogor dikaji dengan analisis skalogram. Analisis skalogram digunakan untuk mengetahui tingkat perkembangan suatu wilayah berdasarkan aktivitas sosial, ekonomi, serta mengidentifikasi tingkat kemampuan wilayah dan aksesibilitas penduduk ke pusat-pusat pelayanan. Ketersediaan fasilitas tidaklah seragam di seluruh kelurahan. Oleh karena itu, penelitian ini dilakukan untuk mengetahui hierarki wilayah kelurahan yang ada di Kota Bogor. Berdasarkan analisis Skalogram, hierarki tertinggi (hierarki 1) cenderung di pusat kota kemudian menyebar ke pinggiran kota cenderung hierarki nya lebih rendah.

Wilayah hierarki 1 adalah kelurahan Babakan, Margajaya, Pabaton dan Tanah Sareal. Wilayah hierarki 2 adalah kelurahan Ciwaringin, Gudang dan Paledang. Wilayah hierarki 3 adalah kelurahan Bantarjati, Baranang Siang, Cibogor, Cibuluh, Empang, Kebon Kelapa, Loji, Menteng, Pasir Mulya, Semplak, Sempur, Sindangsari, Sukaresmi, Tajur dan Tegal Gundil.

Wilayah hierarki 4 adalah Batu Tulis, Bojongkerta, Bondongan, Cibadak, Cilendek Barat, Ciluar, Cimahpar, Ciparigi, Curug, Curug Mekar, Gunung Batu, Harjasari, Kayumanis, Kebon Pedes, Kedung Badak, Kedung Halang, Kedung Jaya, Mekar Wangi, Muarasari, Pakuan, Pamoyanan, Panaragan, Pasirjaya, Pasirkuda, Sindang Barang, Sukadamai, Tanah Baru, Tegallega.

Wilayah hierarki 5 adalah kelurahan Balumbangjaya, Bubulak, Cikaret, Cilendek Timur, Cipaku, Genteng, Katulampa, Kedung Waringin, Kencana, Kertamaya, Lawang Gintung, Mulyaharja, Rancamaya, Rangga Mekar, Sindangrasa, Situ Gede, Sukasari. Hiraki wilayah Kota Bogor dipetakan dalam Gambar 3.

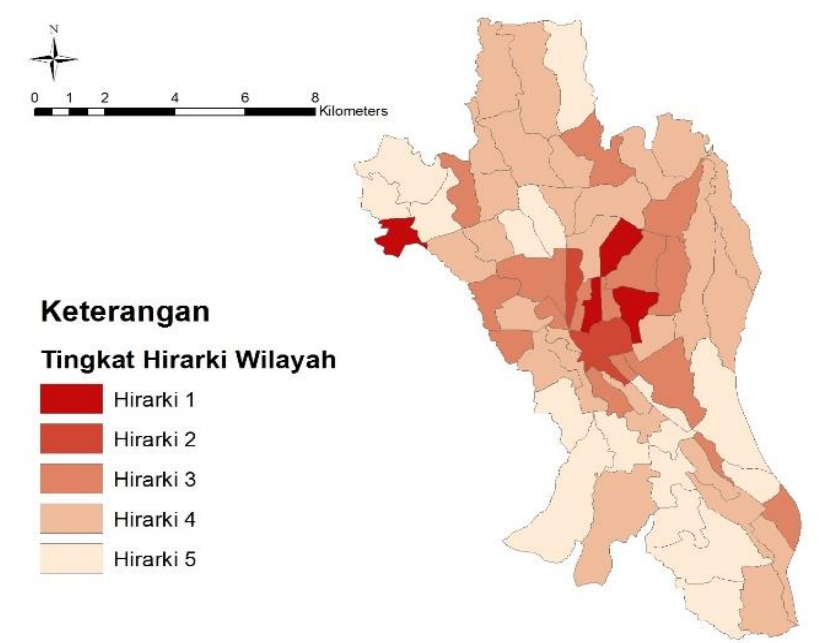

Gambar 3. Peta hierarki wilayah Kota Bogor 


\section{Interaksi Wilayah}

Berdasarkan analisis gravitasi, wilayah pusat kota adalah wilayah pasar atau wilayah penarik pergerakan. Akan tetapi wilayah penarik ini telah pula menyebar ke wilayah tanah sareal, wilayah barat, dan wilayah timur. Wilayah tarikan dan wilayah bangkitan jumlahnya berimbang yaitu masing-masing 34 wilayah.

Wilayah tarikan atau wilayah pasar merupakan wilayah yang cenderung menjadi tempat tujuan pergerakan antara lain wilayah kelurahan Baranangsiang, Batutulis, Bojongkerta, Bondongan, Cimahpar, Cipaku, Curug, Curug Mekar, Empang, Genteng, Gudang, Gunung Batu, Kebon Pedes, Kedung Panaragan, Pasirjaya, Pasirkuda, Rancamaya, Ranggamekar, Sindang Barang, Sukaresmi, Sukasari, Tajur, Tanah Baru, Tegallega, Tegal
Badak, Kedung Halang, Kencana, Kertamaya, Lawang Gintung, Margajaya, Mekarwangi, Menteng, Muarasari, Pakuan, Paledang, Pamoyanan, Pasirmulya, Semplak, Sempur, Sindangrasa, Sindangsari, Situ Gede, Sukadamai dan Tanah Sareal.

Wilayah bangkitan atau wilayah produksi merupakan wilayah yang cenderung menjadi tempat asal pergerakan yaitu wilayah kelurahan Babakan, Babakan Pasar, Balumbangjaya, Bantarjati, Bubulak, Cibadak, Cibogor, Cibuluh, Cikaret, Cilendek Barat, Cilendek Timur, Ciluar, Ciparigi, Ciwaringin, Harjasari, katulampa, kayumanis, Kebon Kelapa, Kedungjaya, Kedung Waringin, Loji, Mulyaharja, Pabaton,

Gundil. Peta Interaksi Wilayah disajikan pada Gambar 4.

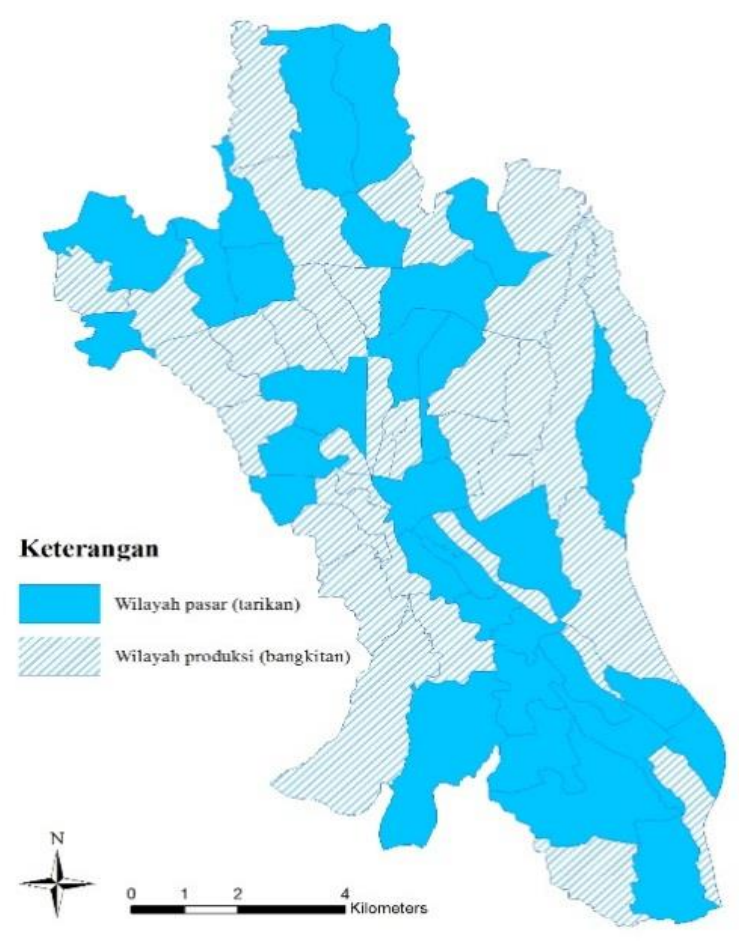

Gambar 4. Peta interaksi wilayah

\section{Pemilihan Pusat Kegiatan Wilayah}

Untuk menentukan wilayah pertumbuhan baru, langkah pertama yang dilakukan adalah melihat regulasi yaitu RTRW Kota Bogor. Dalam RTRW itu sendiri diatur Wilayah Pelayanan. Dalam hal pertumbuhan wilayah pertumbuhan baru, maka dipilih wilayah yang dialokasikan sebagai wilayah perdagangan dan jasa. Wilayah-wilayah tersebut adalah WP B, WP D dan WP E. Peta Wilayah Pelayanan Kota Bogor disajikan pada Gambar 5. 


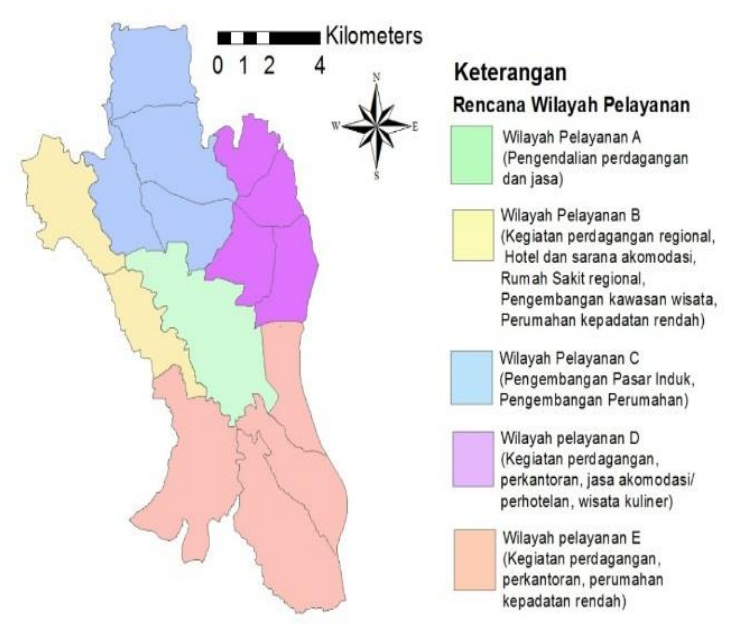

Gambar 5. Peta wilayah pelayanan Kota Bogor

Sumber : Balitbangpeda Kota Bogor, 2015

Pemilihan alternatif pusat kegiatan wilayah dilakukan dengan pendekatan metode MCDM (Multicriteria Decision Making). Pendekatan MCDM digunakan karena mampu mengevaluasi alternatifalternatif berdasarkan banyak kriteria yang tidak dapat dievaluasi dengan pendugaan sederhana atau dengan satu dimensi. Metode MCDM yang digunakan dalam penelitian ini adalah metode AHPTOPSIS.

Sebelum dilakukan pemilihan alternatif pusat kegiatan wilayah dengan metode MCDM TOPSIS, terlebih dahulu dilakukan pembobotan kriteria dengan menggunakan metode AHP. Pembobotan kriteria dengan metode AHP dilakukan dengan wawancara/kuesioner terhadap tiga orang responden yang dianggap ahli/expert, berpengalaman dan mengerti benar permasalahan yang ada mengenai tingkat kepentingan kriteria dalam bentuk pendapat kualitatif.

Dalam menentukan pusat kegiatan wilayah, digunakan analisis TOPSIS pada tiga Wilayah Pelayanan (WP) yang direncanakan untuk kegiatan perdagangan dan jasa yaitu WP B, WP D dan WP E. Peta Alternatif Pusat Kegiatan Wilayah Kota Bogor tersaji dalam Gambar 6.

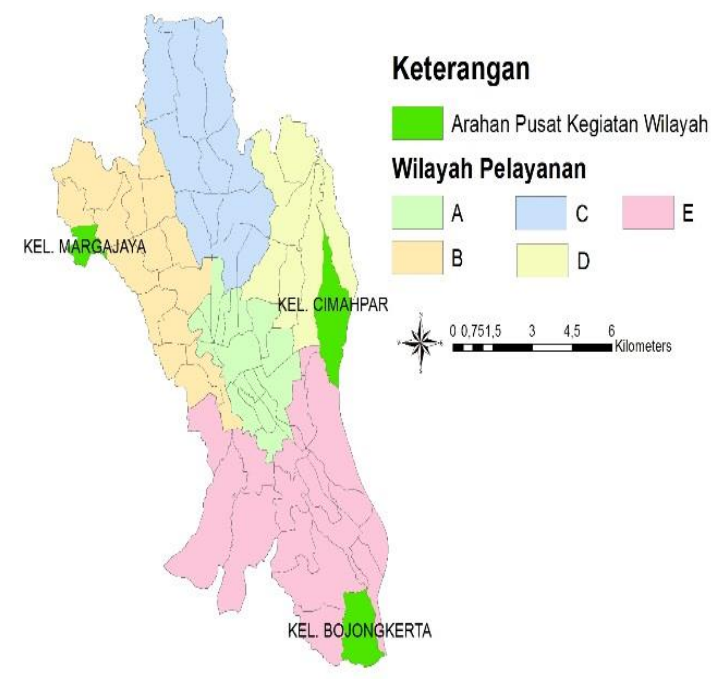

Gambar 6. Peta alternatif

Pusat Kegiatan Wilayah Kota Bogor berdasarkan analisis TOPSIS, wilayah yang berpotensi sebagai arahan pusat kegiatan adalah kelurahan Margajaya, kelurahan Cimahpar dan kelurahan Bojongkerta. Ketiga wilayah tersebut berada tepat di pinggiran Kota Bogor atau berbatasan langsung dengan Kabupaten Bogor. Kelurahan Margajaya dilintasi oleh jalan nasional yaitu Jalan Raya Dramaga dan berbatasan langsung dengan Desa Dramaga, dimana di desa tersebut terdapat perguruan tinggi terkemuka di Indonesia yaitu Institut Pertanian Bogor. Kelurahan Cimahpar memiliki jalan masuk menuju jalan tol lingkar luar Bogor serta berbatasan dengan kawasan Sentul. Kelurahan Bojongkerta dilalui jalan Raya CiawiSukabumi dan jalan tol Bogor Ciawi Sukabumi yang saat ini sedang dalam tahap pengerjaan.

Ketiga wilayah tersebut mendekati akses jaringan jalan lingkar luar, dimana pengembangan jalan lingkar luar (outer ring road) maupun jalan lingkar dalam (inner ring road) merupakan strategi peningkatan aksesibilitas dan keterkaitan antar pusat kegiatan. Ketiga wilayah tersebut dapat mejadi titik simpul jalan lingkar luar (non tol) sebagai alternatif pemecah kepadatan lalu lintas di pusat kota, sehingga penglaju dari luar Kota Bogor tidak perlu lagi melintasi pusat Kota Bogor. 


\section{SIMPULAN}

Terdapat tiga alternatif kelurahan sebagai arahan pusat kegiatan wilayah di Kota Bogor yang ketiganya berada di pinggiran kota Bogor. Ketiga kelurahan tersebut adalah kelurahan Margajaya, Cimahpar dan Bojongkerta. Diantara ketiga wilayah yang menjadi arahan pusat kegiatan wilayah Kota Bogor berdasarkan penelitian ini, hanya Margajaya yang berada pada hierarki 1, akan tetapi jika dilihat lebih jauh, hubungan dengan wilayah tetangganya yang berada di Kabupaten Bogor, ketiganya memiliki nilai strategis. Margajaya berbatasan dengan Dramaga, dimana terletak perguruan tinggi terkemuka di Indonesia yaitu IPB. Cimahpar dapat tembus ke jalan tol Lingkar Luar Bogor yang diprediksi akan terus berkembang. Bojongkerta dilalui oleh jalan tol Bogor Ciawi Sukabumi, juga berpotensi sebagai wilayah yang akan terus berkembang. Berdasarkan analisis gravitasi, ketiganya merupakan wilayah tarikan (pasar), yaitu wilayah yang cenderung menjadi tempat tujuan pergerakan (destination). Dari segi kepadatan lalu lintas, Cimahpar dan Bojongkerta memiliki kepadatan wilayah yang rendah, sedangkan Margajaya memiliki kepadatan lalu lintas wilayah dengan kategori sedang.

\section{DAFTAR PUSTAKA}

Bau, Q. D., Hartono, Parikesit, D., \& Gunawan T. (2013). Pengembangan Metode Bangkitan dan Tarikan Perjalanan Berdasarkan Citra Quickbird. Jurnal Transportasi, 13(2), 105-114.

Direktorat Bina Jalan Kota, Direktorat Jenderal Bina Marga, Kementrian Pekerjaan Umum. (1997). Manual Kapasitas Jalan Indonesia.

Fitriana, A.N., Harliana, \& Handaru. (2015). Sistem Pendukung Keputusan untuk Menentukan Prestasi Akademik Siswa dengan Metode TOPSIS. CITEC Journal, 2(2), 153-164.
Gulo, Y. (2015). Identifikasi Pusat-Pusat Pertumbuhan Wilayah Pendukungnya dalam Pengembangan Wilayah Kabupaten Nias. Jurnal Widyariset, 18(1), 37-48.

Jati, V. I. M., \& Christanto, J. (2012). Kajian Perkembangan Permukiman Wilayah Peri Urban di Sebagian Wilayah Kabupaten Sukoharjo Tahun 2001-2007. Jurnal Bumi Indonesia, 1(1), 1-8.

Kumalasari, D., Soemarno, \& Wicaksono, A. (2011). Pengaruh Guna Lahan terhadap Tarikan Pergerakan, Biaya Kemacetan dan Biaya Kecelakaan (Di Jalan KH. Abdul Fatah-Jalan Kapten Kasihin Tulungagung). Rekayasa Sipil, 5(3), 168179.

Panuju, D. R. \& Rustiadi, E. (2012). Teknik Analisis Perencanaan Pengembangan Wilayah. Bogor: Bagian Perencanaan Pengembangan Wilayah, Departemen Ilmu Tanah dan Sumberdaya Lahan, Institut Pertanian Bogor.

Rachmawati, R. \& Kurniawan, A. (2006). Pola Pergerakan Keruangan Penduduk Pinggiran Kota dan Pngaruhnya terhadap Konsentrasi Kegiatan di Kota Yogyakarta. Majalah Geografi Indonesia, 20(1), 20-31.

Rui, Y., Ban, Y.,Wang, J., \& Haas, J. (2013). Exploring the patterns and evolution of self organized urban street networks through modeling. The European Physical Journal B 86, 74.

Sekretariat Daerah Kota Bogor. (2011). Peraturan Daerah Kota Bogor No.8 Tahun 2011 tentang Rencana Tata Ruang Wilayah Kota Bogor.

Sudarya, D., Sitorus, S. R. P., \& Firdaus, M. (2013). Analisis Perkembangan Ekonomi Wilayah untuk Arahan Pembangunan Kecamatan di Wilayah Pesisir Kabupaten Garut. Jurnal Ilmiah Geomatika, 19(2), 134-140.

Tamim, 0. Z. (2000). Perencanaan dan Pemodelan Transportasi. Cetakan Kedua. Bandung: Penerbit ITB 